\title{
Lajos Jordáky
}

Lajos Jordáky was a historian, a sociologist, a literary critic, a political theorist, and, like so many of his fellow central European intellectuals, he was also deeply committed to social and political ideals and active in bringing them to fruition. If I could use a single word to characterize his rich and many-sided career, it would be "humanist," for understanding and sympathy for his fellow man pervaded all his work and gave it purpose and unity.

Jordáky was born in Cluj on September 6, 1913, and died there on November 30, 1974. His life was in a sense determined by the history of his native city and province. He grew up in a family with strong socialist traditions; in 1933, already well versed in the writings of leading socialist thinkers, he joined the Romanian Social Democratic Party. For the next thirteen years he was in the forefront of socialist and working-class movements in Transylvania. At the same time, he pursued an academic career, taking a doctorate in philosophy at the University of Cluj. He remained in Cluj during the Second World War and the Hungarian occupation of northern Transylvania. It was a difficult time for him and other socialists. Their opposition to the war and their democratic sentiments brought continual harassment and arrest by the security police. After the occupation of Cluj by Soviet and Romanian troops in October, 1944, Jordáky became a key figure in the political reorganization of northern Transylvania, serving as political secretary for the Cluj committee of the Romanian Communist Party and a member of the secretariat of the North Transylvanian Committee.

The main problem that confronted him and his colleagues in 1945 was the age-old nationality conflict in Transylvania. Jordáky was convinced that the future prosperity and democratic development of all the peoples of Transylvania depended on a speedy and just solution of the nationality problem. No people, he once said, could be free, if it oppressed another, and he was now determined to assure full equality of rights to Romanians, Magyars, Germans, and Jews. From his own studies of the nationality problem, both in Transylvania, and in other parts of Europe, he had concluded that economic inequality created national conflicts and oppression. He placed his own hopes for a solution in the principles of democratic socialism, for which he thought the time had at last come in that heady atmosphere of democratic pronouncements and sanguine promises of a "new life" that followed the end of the war. Because of the mixed nature of the population in northern Transylvania and the impossibility of drawing clearcut 
boundaries between Romanians and Magyars, he favored an autonomous status for the area, which would henceforth belong exclusively neither to Romania nor to Hungary but would serve as an intermediary between them, turning old rivals into new friends. Autonomy was not to be, however, since the Soviet Union decided to award the territory to Romania in March, 1945, but Jordáky continued his efforts to assure equality of national rights within what he hoped would be a democratic Romania.

Jordáky's public career ended in 1946 under circumstances that have not yet been fully elucidated. Some recent commentators have referred to his "mistakes," but they give no details and pass over the next ten to fifteen years in silence. It was another difficult time for him, as it was for many in Romania during the years when the Communist regime was consolidating its power. He was imprisoned on two occasions, once for three years (1952-1955) and again for a shorter time after the Hungarian uprising of 1956. My own interpretation of these events is that Jordáky remained faithful to the principles of democratic socialism when other goals and other methods of achieving them were the order of the day.

In 1958 Jordáky became a research associate of the Institute of History of the Romanian Academy in Cluj and was consequently able to pursue his scholarly interests and resume publishing on a modest scale. In the last few years of his life the volume of his publications increased enormously, as one book after another came off the presses, not only in Bucharest and Cluj but now also in Budapest. His death suddenly deprived those who knew him (and a much wider audience, too) of the benefit of his wisdom and experience, some of which will remain in manuscript, some of which was never written.

As a historian and sociologist, Jordáky displayed a boundless curiosity and possessed a breadth of vision and a scholarly method that gave substance to whatever he put on paper. He ranged over a great variety of subjects: the working-class movement in his native province, particularly in two studies, "A cluji ipari munkásság" [The Cluj Industrial Workers] and "A téglagyári munkások élete" [The Life of the Brickyard Workers], both of which were published in the Cluj monthly, Korunk, in 1938 and were based upon the latest sociological methods of investigation; the contemporary problems of international socialism, in such books as Spanyolország [Spain] (1939) and $A$ francia szocializmus három nagy alakja: Jaurès, Guesde, Lafargue [Three Great Figures of French Socialism: Jaurès, Guesde, Lafargue] (1945); the history of socialist thought, particularly in studies of Saint-Simon; the theoretical and sociological aspects of historical science, as, for instance, in Szocializmus és történettudomány [Socialism and Historical Science] (1974); the nationality problem in Europe between the two world wars: 
"A baszk nacionalizmus útja" [The Way of Basque Nationalism] and "Bretonok" [The Bretons], both published in Korunk in 1937; the Hungarian theater in Transylvania, as, for example, in Janovics Jenö és Poór Lili. Két szinész arcképe [Jenó Janovics and Lili Poór. Portraits of Two Artists] (1971); and the role of literary creativity in modern society, especially as in $A$ szocialista irodalom útján [Along the Path of Socialist Literature] and Irodalom és világnézet [Literature and World View], both published in 1973.

Among his works dealing specifically with the Habsburg monarchy was his study of the peasant uprising of 1784 in Transylvania led by Horia. Written in 1937, it was the first attempt in Hungarian historical writing in Romania to analyze this event from the standpoint of historical materialism. Jordáky also contributed to a variety of bibliographical projects. One of his bibliographical articles was "The History of the Habsburg Monarchy (1789-1918) in Romanian Historiography since 1945," which appeared in Volume IV-V (19681969) of the Austrian History Yearbook.

What may be Jordáky's most important piece on the history of Transylvania is his study of the formation of the Romanian National Party, A Román Nemzeti Párt megalakulása (Budapest, 1974). Beginning his study with a discussion of the awakening of Romanian national consciousness at the end of the eighteenth and the early years of the nineteenth century and its first modern expression during the revolution of 1848 , he describes the major events that preceded the foundation of a united party in 1881. Based largely on Romanianlanguage sources, especially the correspondence of leading politicians, his account is fair to all parties. Yet it has an importance beyond the information it contains; it helps to explain why Jordáky, despite his many other preoccupations, took time to deal with a subject mainly concerned with the internal history of the Romanians. He wanted to show two things: first, that a Transylvanian Magyar could be fair in treating a sensitive chapter of Romanian-Magyar relations; and, second, that he could regard the formation of a Romanian political party as a part of his own historical heritage because Transylvania/ Romania was his country, too.

Lajos Jordáky's friends will miss the warmth and animation of the get-togethers at the end of the day in his great book-lined living room. They will miss the honesty and humanity that he brought to the study of history. 